\title{
Oro Nasal Communication Closure in Smoker Patient: Case Report
}

\section{De Oliveira JCS, De Almeida RS, Faverani LP, Bassi APF, Sonoda CS and Luvizuto ER}

Department of Surgery and Integrated Clinic, Araçatuba Dental School, Brazil

\begin{abstract}
Various methods have been described in literature for closure of the ora antral communications. The use of buccal fat is an alternative primarily because it is easy technique, minimal complications and morbidity for the patient. Authors present a challenging clinical case of closure of oro antral communication once the patient is a smoker and has had a fistula formation with purulent drainage.
\end{abstract}

Keywords: Buccal pad fat; Pedicled graft; Oroantral communication; Buccal flap; Maxillary sinus

\section{Introduction}

Buccal fat pad in recent years has become a well-accepted graft for covering intraoral defects [1]. This structure is also known by the eponym Bichat, since it was the french anatomist to discover this tissue in $1801[1,2]$.

The buccal fat pad is a supple and lobulated mass, easily accessible and mobilized [3], located between the buccinator muscle and the mandibular ramus, separating the masticatory muscles from each other and often considered to be a nuisance when encountered in intra-oral procedures such as facial bone osteotomies, elevation of buccal flap or procedure on Stenson's duct [1].

Egyedi [4] was the first to describe the use of Bichat fat pad with surgical description for closure of oro antral communications. This type of complication is quite usual and described in the clinical literature after the extraction of maxillary posterior teeth, especially in the presence pneumatization of the maxillary sinus $[5,6]$.

Authors aimed to describe a case of closure of oro antral communication with challenging clinical frame, since the patient is smoker two-month latency time of the buco sinus fistula.

\section{Case Report}

A 47-year-old woman was referred to the dental clinic of Araçatuba Dental School complaining of severe headaches, especially when waking up, and development of sinusitis with an unpleasant taste in the mouth two months ago. The patient is a smoker, without any disease or allergy. She has reported all laboratory tests within normal limits, including periodic visits to the cardiologist and this case has already been evaluated by the otolaryngologist.

Intraoral physical examination has shown lack of healing of the socket corresponding to the tooth 26 , with the presence of chronic purulent secretion in alveolar extraction. For purposes of evidence, the Valsalva test was performed, which was positive, therefore confirming the clinical diagnosis of oro antral communication. Immediately a panoramic radiograph was performed, which noted the absence of bone continuity on the floor of the maxillary sinus (Figures 1 and 2).

Possible forms of treatment were exposed to the patient, always warning of the risk of failure, regardless of the therapeutic approach chosen, because it is a heavy smoker patient with presence of fully formed fistula, and sinusitis.

After administration of local anesthesia with articaine hydrochloride $4 \%$ with 1:100.000 epinephrine, the fistula was removed through an incision skirting corresponding to the tooth socket 26. After extensive washing of the area with $0.9 \%$ saline solution, then two relaxing incisions were made, an earlier and a more posterior to the region. Preceding the detachment, held several incisions into the periosteum and muscle layer in order to expose the fat pad of Bichat. Taken exposure, the tissue was pulled carefully with forceps dietrich until fully rested and covering the defect without tension. The buccal fat pad was sutured with 4-0 Vycril and retail was sutured with 4-0 Vycril and some points were given with 5-0 nylon (Figures 3 and 4).

After surgery, Antibiotic therapy with $400 \mathrm{mg}$ metronidazole associated with $500 \mathrm{mg}$ amoxicillin was prescribed for the patient 3 times a day for 15 days.

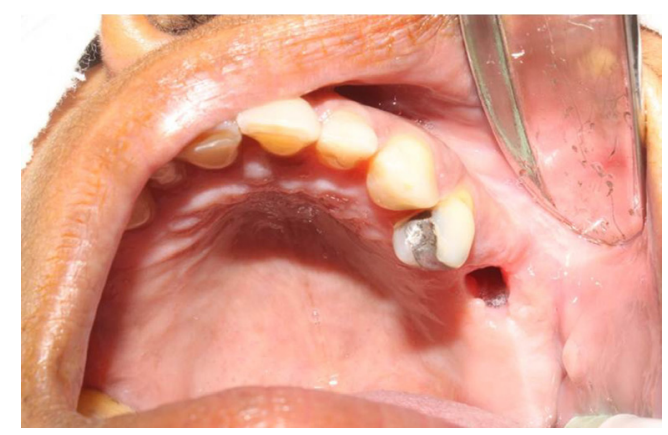

Figure 1: Initial clinical image

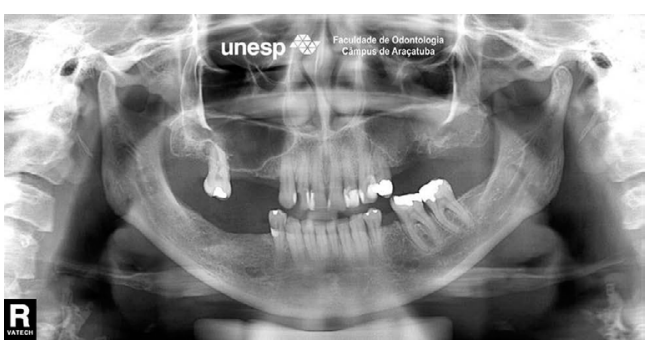

Figure 2: Preoperative panoramic radiograph.

*Corresponding author: Eloá Rodrigues Luvizuto, Department of Surgery and Integrated Clinic, Araçatuba Dental School, Rua José Bonifácio 1193 Araçatuba/SP/ Brazil, CEP: 16015-050, Tel: +55 (18) 98111-9256; E-mail: eloaluvizuto@hotmail.com

Received February 22, 2014; Accepted March 1, 2014; Published March 28 2014

Citation: De Oliveira JCS, De Almeida RS, Faverani LP, Bassi APF, Sonoda CS et al. (2014) Oro Nasal Communication Closure in Smoker Patient: Case Report. Dentistry 4: 226. doi:10.4172/2161-1122.1000226

Copyright: ㄷ 2014 De Oliveira JCS, et al. This is an open-access article distributed under the terms of the Creative Commons Attribution License, which permits unrestricted use, distribution, and reproduction in any medium, provided the original author and source are credited. 


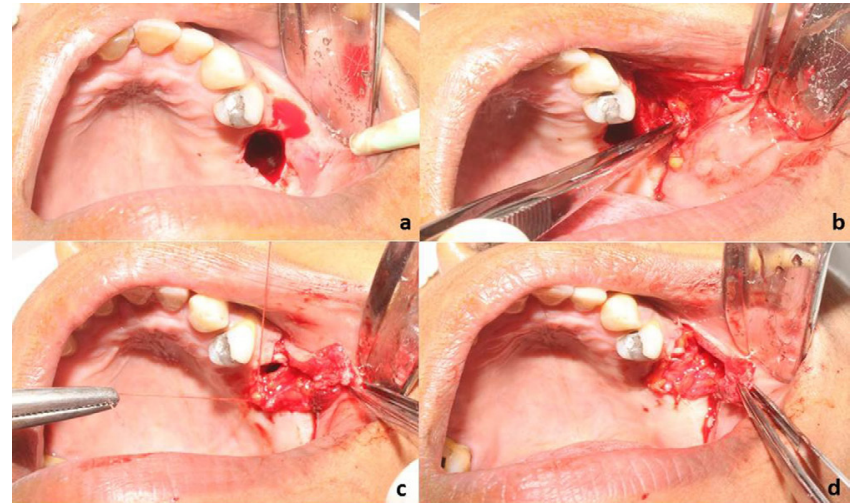

Figure 3: (a) Removal of the fistula, (b) exposure of buccal fat pad, (c,d) closing the first layer.

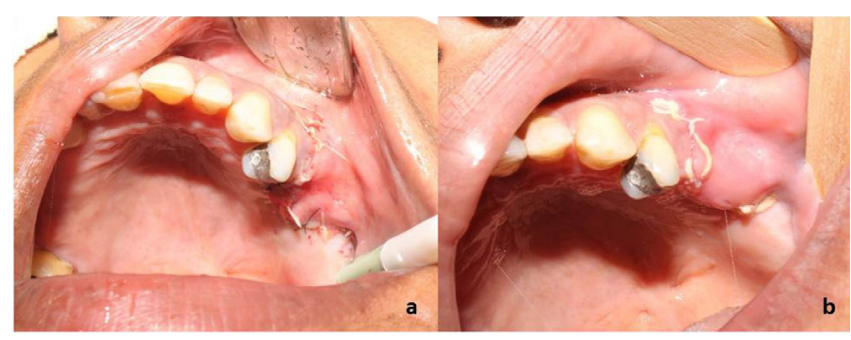

Figure 4: (a) Total closure right after surgery, (b) aspect of the area one week postoperative.

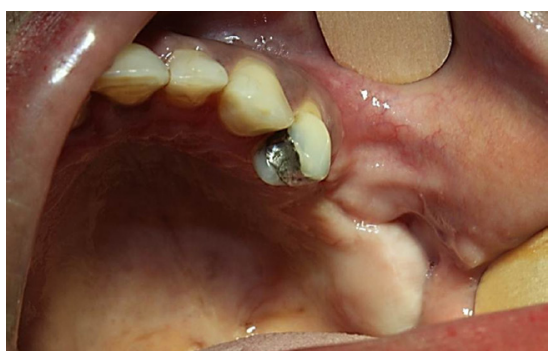

Figure 5: One year follow-up after surgery.

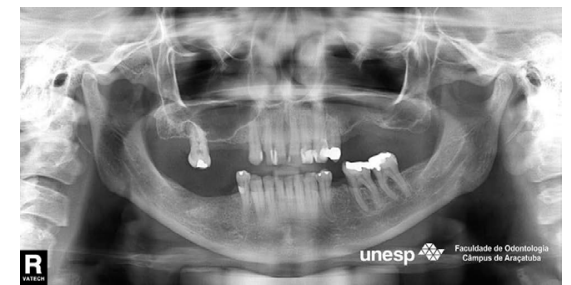

Figure 6: One year follow-up panoramic radiograph.

The post-operative instructions were to avoid blowing your nose, sneezing open mouth, sucking as avoid using straws and smoking, which were light and puffs fewer cigarettes per day. Moreover, continued use has been prescribed antibiotics and $750 \mathrm{mg}$ of paracetamol 6 in 6 hours for two days and $100 \mathrm{mg}$ of nimesulide 12 in 12 hours for 4 days.

Periodic visits were scheduled for 1 year and at the end we can infer the success of treatment (Figures 5 and 6), with total closure of oro antral fistula, with reported total cure of headache with sinusitis treatment together with an otolaryngologist.

\section{Discussion}

Oro antral communication is an unnatural communication between the oral cavity and maxillary sinus and when it fails to close spontaneously, it remains patent and is epithelialized so that oro-antral fistula develops [7], as occurred in the case presented.

Surgical closure of an antral perforation is indicated if the opening is greater than $4-5 \mathrm{~mm}$ at the time of injury, if a sinus disease is present whatever the size of the opening, and if the communication is persistent [8]. As presented in this case, since the formation of the fistula was confirmed by the latency and chronicity of constant communication with purulent debt, beyond the patient's pain complaints.

Numerous surgical techniques have been described in the literature, mostly based on mobilizing the tissue and advancing the resultant flap into the defect [7]. Techniques, from soft tissue-only closure to the use of composite closures involving alloplastic materials such as gold, acrylic, or bone grafts, have described. Soft tissue-only flaps include the buccal advancement flap, buccal fat pad flap, a combination of the buccal fat pad and advancement flap, the buccinators myomucosal flap, and the vascularized palatal island flap [5]. The authors decided to use the Bichat fat pad because of its reliability, ease of harvest, low complication rate, rich blood supply, simple procedure, and minimal discomfort to patient [1] in association an advancement flap.

The main disadvantage observed in this form of treatment is reported by the event displaying loss of the oral vestibule, wherein the patient will need to undergo sulcoplasty technique. However, because of the initial clinical status of the patient, this disadvantage becomes easily minimized for the restoration of homeostatic balance oro antral. Amazingly, this technique also improves the physiologic functions of the cheek, for example, suppleness and elasticity [3].

Therefore, as observed in the clinical case, there is the possibility of obtaining successful use of fatty body for closing oro antral fistula, even the most unfavorable ones.

\section{Conclusion}

The use of pedicle of the buccal fat pad for reconstruction of defects including oro antral communications is already more than consolidated in the literature, being easy to perform and convenient for both patients and for the operator. Furthermore, it's located in the same surgical field as the defect to cover, therefor diminishing the risk of infection $[1,3]$.

\section{References}

1. Bither S, Halli R, Kini Y (2013) Buccal fat pad in intraoral defect reconstruction J Maxillofac Oral Surg 12: 451-455.

2. Shoja MM, Tubbs RS, Loukas M, Shokouhi G, Ardalan MR (2008) Mariefrancois xavier bichat (1771-1802) and his contributions to the foundations of pathological anatomy and modern medicine. Ann Anat 190: 413-420.

3. Yeh CJ (1996) Application of the buccal fat pad to the surgical treatment of oral submucous fibrosis. Int J Oral Maxillofac Surg 25: 130-133.

4. Egyedi $P$ (1977) Utilization of the buccal fat pad for closure of oro-antral and/or oro-nasal communications. J Maxillofac Surg 5: 241-244.

5. Weinstock RJ, Nikoyan L, Dym H (2014) Composite three-layer closure of oral antral communication with 10 months follow-up-a case study. J Oral Maxillofac Surg 72: 266.

6. Godfrey PM (1193) Sinus obliteration for chronic oro-antral fistula: A case report. Br J Plast Surg 46: 341-342. 
Citation: De Oliveira JCS, De Almeida RS, Faverani LP, Bassi APF, Sonoda CS, et al. (2014) Oro Nasal Communication Closure in Smoker Patient: Case Report. Dentistry 4: 226. doi:10.4172/2161-1122.1000226

Page 3 of 3

7. Batra H, Jindal G, Kaur S (2010) Evaluation of different treatment modalities for closure of oro-antral communications and formulation of a rational approach. J Maxillofac Oral Surg 9: 13-18.
8. Nezafati S, Vafaii A, Ghojazadeh M (2012) Comparison of pedicled buccal fat pad flap with buccal flap for closure of oro-antral communication. Int $\mathrm{J}$ Oral Maxillofac Surg 41: 624-628. 